\title{
RAIINSTEK
}

\section{RANCANG BANGUN SISTEM PENDUKUNG KEPUTUSAN PENENTUAN JENIS BEASISWA MENGGUNAKAN KNN}

\author{
Ludfiyatul Qoiriyah $^{1}$, Hari Lugis Purwanto ${ }^{2}$, Wiji Setiyaningsih ${ }^{3}$ \\ Sistem Informasi, Universitas Kanjuruhan Malang ${ }^{1,2,3}$ \\ $\underline{\text { ludfiyatulqoiriyah@gmail.com, hari_lugis.unikama.ac.id, wiji@unikama.ac.id }}$
}

\begin{abstract}
Abstrak. Beasiswa merupakan pembiayaan dari orang lain, perusahaan, universitas, dan lembaga lain yang salah satunya yaitu oleh Universitas Kanjuruhan Malang. Selama ini proses penyeleksian beasiswa dilakukan staf dengan menginputkan data mahasiswa satu persatu dalam excel. Pengelolaan data secara manual yang dilakukan oleh staf tersebut dapat meningkatkan terjadinya kesalahan, seperti terdapat data yang sama atau duplikasi data, penginputan data yang salah dan pengecekan ulang pada data dalam jumlah besar dapat membuat ketelitian staf menurun. Hal tersebut dapat mempengaruhi hasil penentuan beasiswa sehingga tidak sesuai dengan kriteria dan kemungkinan terjadinya pengulangan penerimaan beasiswa pada mahasiswa yang sama semakin besar. Metode K-Nearest Neighbor (KNN) merupakan sebuah metode yang mengklasifikasikan data dan memiliki konsistensi yang kuat dengan melakukan klasifikasi berdasarkan menghitung kedekatan jarak antara kasus baru dengan kasus lama. Sistem menghasilkan hasil penentuan jenis beasiswa berdasarkan kriterian yang telah ditentukan, yaitu IPK, semester, penghasilan dan tanggungan orang tua. Berdasarkan hasil pengujian user acceptance test yang dilakukan, dapat diambil kesimpulan bahwa penerapan metode Nearest Neighbor (KNN) untuk menentukan jenis beasiswa memberikan hasil yang diharapkan dan diterima dengan baik dengan presentase hingga $86 \%$ serta dapat membantu mempermudah kinerja staf.
\end{abstract}

Kata Kunci: system pendukung keputusan; beasiswa; knn

\section{PENDAHULUAN}

Pendidikan merupakan aspek yang penting dalam kehidupan suatu bangsa bahkan mendapatkan pengajaran adalah hak setiap warga negara. Pendidikan yang layak bagi setiap warga negara menentukan maju dan tidaknya suatu bangsa. Menyadari akan pentingnya pendidikan pemerintah dan lembaga pendidikan bahkan memiliki program pendidikan gratis dan program beasiswa. Beasiswa adalah pembiayaan bukan bersumber dari pendanaan sendiri atau orang tua akan tetapi diberikan oleh pemerintah, sebuah perusahaan, kedutaan, universitas, maupun lembaga pendidikan (Helilintar, dkk, 2016).

Universitas Kanjuruhan Malang merupakan salah satu dari berbagai perguruan tinggi swasta di Kota Malang dan memiliki program studi yang sebagian besar adalah program studi berfokus pada pendidikan. Perguruan tinggi swasta ini bernaung di bawah bendera Yayasan Perkumpulan Pembina Lembaga Pendidikan Perguruan Tinggi PGRI (PPLP PT PGRI). Ada beberapa macam beasiswa yang ditawarkan di Universitas Kanjuruhan Malang, seperti Beasiswa Peningkatan Prestasi Akademik (PPA), Beasiswa PPLP PT PGRI, Beasiswa BNI dan Beasiswa CIMB Niaga.

Pada kondisi saat ini, proses penyeleksian beasiswa dilakukan staf dengan menginputkan data mahasiswa satu persatu dalam excel. Akan tetapi hal tersebut dapat menyita waktu karena dibutuhkan ketelitian dalam pemrosesan, pengecekan dan penginputan data mahasiswa dengan benar karena mengingat banyaknya berkas yang diserahkan sesuai dengan persyaratan beasiswa. Pengelolaan data secara manual yang dilakukan oleh staf tersebut dapat meningkatkan terjadinya kesalahan, seperti terdapat data yang sama atau duplikasi data, penginputan data yang salah dan pengecekan ulang pada data dalam jumlah besar dapat membuat ketelitian staf menurun. Hal tersebut dapat mempengaruhi hasil penentuan beasiswa sehingga tidak sesuai dengan kriteria dan kemungkinan terjadinya pengulangan penerimaan beasiswa pada mahasiswa yang sama semakin besar. Akan tetapi, 
pihak penyeleksi diharapkan cepat dan tepat dalam memutuskan siapa yang berhak menerima beasiswa yang diusulkan sehingga tidak efektif jika masih dilakukan secara manual.

Berdasarkan uraian permasalahan diatas, maka untuk mengatasi permasalahan di Bagian BAK terkait penelitian tersebut dibutuhkan Sistem Pendukung Keputusan Penentuan Jenis Beasiswa Menggunakan Metode $K-N N$ untuk membantu staf BAK dalam menentukan jenis beasiswa. Sistem pendukung keputusan ini bertujuan untuk mempermudah kinerja staf dalam menentukan beasiswa sehingga dapat memanajemen data beasiswa dan mahasiswa, melihat data pengajuan berdasarkan tahun pelaksanaannya, menentukan beasiswa dengan cepat dan tepat serta dapat melihat laporan pengajuan beasiswa.

\section{METODE PENELITIAN}

\section{A. Metode K-Nearest Neighbor}

Algoritma K-Nearest Neighbor merupakan sebuah metode pengklasifikasian data dengan melakukan klasifikasi berdasarkan perhitungan jarak terdekat antara kasus baru dengan kasus lama berdasarkan kecocokan bobot yang ada (Yulianti \& Nurdia, 2018). Kualitas data pada penelitian dapat mempengaruhi nilai $\mathrm{K}$ yang digunakan pada metode ini. Efek Noise pada kalasifikasi dapat dikurangi dengan Nilai K yang tinggi namun membuat batasan antara masing-masing klasifikasi menjadi lebih kabur. Adapun langkah-langkah perhitungan dalam metode K-Nearest Neighbor adalah sebagai berikut:

1. Menentukan Parameter K, dimana K merupakan jumlah tetangga terdekat yang digunakan

2. Menghitung kuadrat jarak Euclid (queri instance) pada masing-masing objek terhadap data sampel yang diberikan

$$
d(x, y)=\sqrt{\sum_{i=1}^{n}\left(x_{i}-y_{i}\right)^{2}}
$$

3. Mengurutkan jarak objek-objek tersebut ke dalam kelompok yang mempunyai jarak Euclid paling kecil

4. $\quad$ Mengumpulkan setiap kategori Y (klasifikasi Neirest Neighbor)

5. Memakai kategori Neirest Neighbor yang paling banyak muncul maka dapat dijadikan sebagai prediksi

\section{B. Model Pengembangan Waterfall}

Pada penelitian ini dilakukan dengan menggunakan metode penelitian dan pengembangan (research and development). Model Waterfall sering disebut siklus hidup klasik (classic life cycle) yang menggambarkan pendekatan yang sistematis dan berurutan pada pengembangan perangkat lunak (Pressman, 2015). Langkah-langkah pengembangan dalam pendekatan waterfall secara ringkas model pengembangan adalah sebagai berikut:

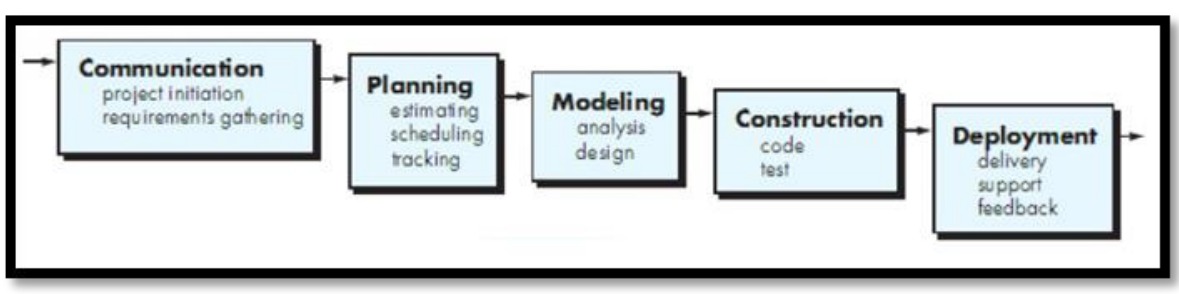

Gambar 1. Model Pengembangan Waterfall

\section{Blackbox Testing}


Metode uji coba blackbox merupakan pengujian yang fokus pada persyaratan fungsional dari suatu software. Karena itu ujicoba blackbox memungkinkan pengembang software untuk membuat himpunan kondisi input yang akan melatih seluruh keperluan fungsional suatu program. Ujicoba blackbox bukan merupakan alternatif dari ujicoba whitebox, tetapi merupakan pendekatan yang melengkapi untuk menemukan kesalahan lainnya, selain menggunakan metode whitebox (Mustaqbal, dkk, 2015).

\section{HASIL DAN PEMBAHASAN}

A. Model Waterfall

1. Communication

Merupakan tahapan paling awal dengan melakukan dua tahapan yaitu (1) observasi dan wawancara untuk mengumpulkan data-data dan fakta permasalahan dilapangan serta (2) penyusunan aktor yang terlibat didalam sistem. Tahapan tersebut diperlukan dalam mendefinisikan fitur dan fungsi software atau analisis kebutuhan sistem. Selain itu pengumpulan data-data juga dapat dilakukan melalui studi literatur. Peneliti melakukan studi lapangan langsung kepada staf dan Kepala Bagian Biro Admisnistrasi Kemahasiswaan (BAK)

2. Planning

Tahapan perencanaan bertujuan untuk mengetahui estimasi tugas yang dilakukan, sumber daya yang diperlukan dalam membuat sistem, resiko-resiko yang dapat terjadi, produk yang akan dihasilkan serta dilakukan penjadwalan untuk pekerjaan yang akan dilaksanakan dan tracking yang bertujuan untuk mengetahui sejauh mana proses pengerjaan sistem. Dimulai dari penjadwalan pengerjaan mastering beasiswa dan mahasiswa kemudian transaksi penentuan beasiswa beserta penerapan rumus metode $K$ $N N$ serta bagian akhir yakni pengerjaan keluaran laporan. Berikut merupakan alur sistem yang digambarkan pada gambar 2.

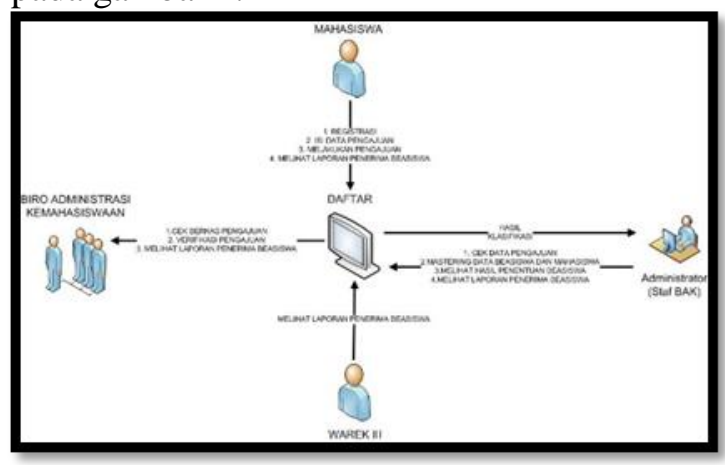

Gambar 2. Block Diagram

3. Modelling

Tahapan ini merupakan tahap perancangan dan pemodelan arsitektur sistem yang berfokus pada perancangan struktur data, arsitektur software, tampilan interface, dan algoritma program. Pada penelitian ini perancangan tersebut menggunakan $U M L$ untuk memperjelas alur sistem dengan menggunakan aplikasi Astah Community serta peniliti juga menggunakan aplikasi Pencil dalam merancangan tampilan interface Sistem Pendukung Keputusan Penentuan Jenis Beasiswa. Berikut adalah gambaran perancangan desain interface dalam tampilan sistem seperti pada gambar 3, gambar 4 dan gambar 5. 


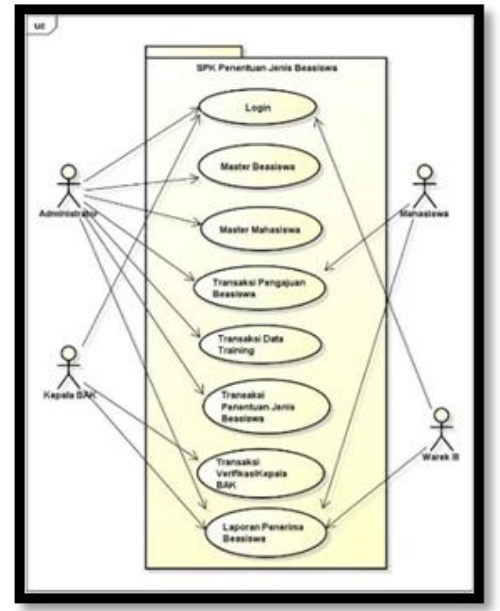

Gambar 3. Use Case Utama

Sistem pendukung keputusan ini memiliki aktor yang terlibat dalam penenlitian ini dapat dibagi menjadi empat yaitu, mahasiswa, administrator atau Staf BAK, Kepala BAK dan Warek III serta memiliki hak akses sesuai penggambaran use case utama.

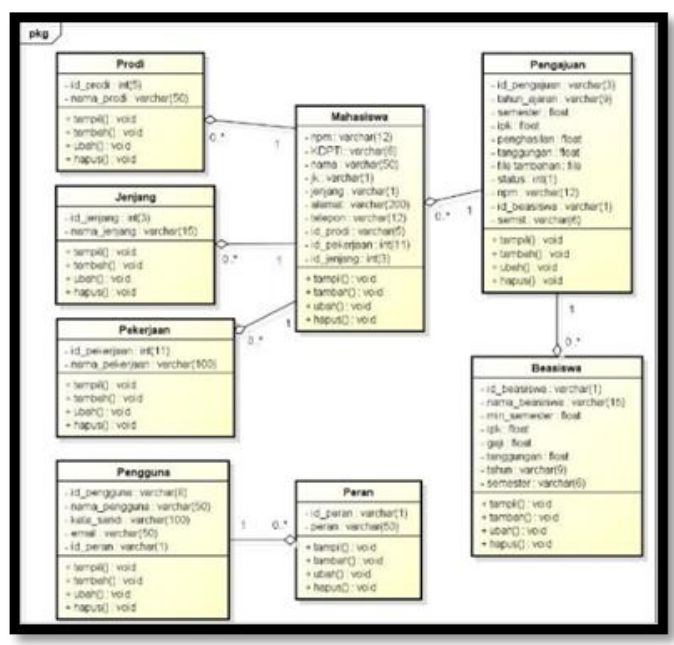

Gambar 4. Class Diagram

Gambar 4 menjelaskan alur pada database sistem, dimana class diagram ini terdapat delapan class yang memiliki relasi antara satu dengan yang lain sesuai dengan alur proses dan mastering yang dibutuhkan dalam aplikasi penentuan jenias beasiswa ini.

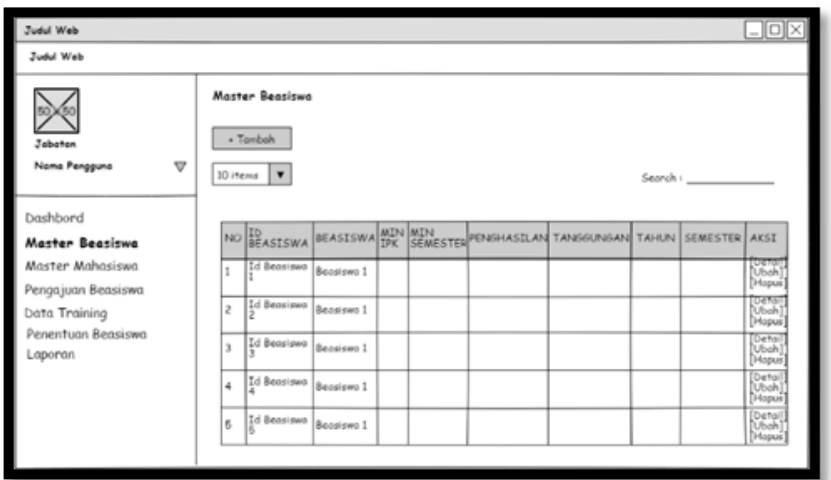

Gambar 5. Perancangan Tampilan Mastering Beasiswa

4. Construction (Code \& Test) 
Merupakan tahapan pembuatan kode atau coding sesuai pada hasil tahapan perancangan. Software yang digunakan adalah Editor Sublime untuk memudahkan peneliti dalam proses pemrograman. Kemudian dilakukan pengujian atau testing terhadap sistem yang dibuat setelah proses pengkodean selesai. Pengujian tersebut menggunakan uji blackbox testing. Selain itu, dilakukan pengujian user acceptance test dengan menyebar kuisioner pada pengguna (Agustina \& Suprianto, 2018).

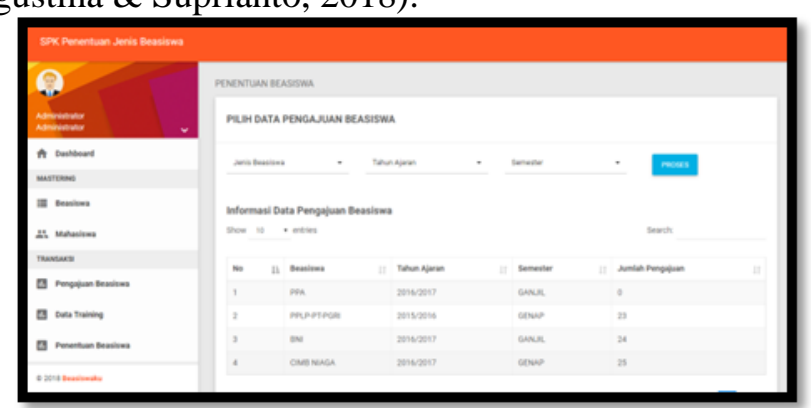

Gambar 6. Tampilan Transaksi Penentuan Beasiswa

Pengujian blackbox testing dilakukan dengan membuktikan bahwa semua objek dalam sistem dapat berjalan sesuai fungsi yang diberikan. Pada tabel 1 menjelaskan hasil pengujian blackbox seperti berikut:

Tabel 1. Pengujian Blackbox

\begin{tabular}{|c|c|c|c|c|}
\hline No & Fungsi & Pengujian & Hasil Yang Diharapkan & Keterangan \\
\hline 1 & Login & $\begin{array}{l}\text { Memasukan id pengguna dan katasandi } \\
\text { sesuai data pengguna }\end{array}$ & $\begin{array}{l}\text { Masuk pada halaman } \\
\text { dashboard sesuai hak } \\
\text { akses pengguna }\end{array}$ & Berhasil \\
\hline 2 & $\begin{array}{l}\text { Mastering } \\
\text { Beasiswa }\end{array}$ & $\begin{array}{l}\text { Pilih menu master beasiswa kemudian } \\
\text { tekan tombol tambah, ubah dan hapus } \\
\text { serta sistem akan menampilkan } \\
\text { perubahan data beasiswa }\end{array}$ & $\begin{array}{l}\text { Menampilkan data dan } \\
\text { menyimpannya ke dalam } \\
\text { database. }\end{array}$ & Berhasil \\
\hline 3 & $\begin{array}{l}\text { Mastering } \\
\text { Mahasiswa }\end{array}$ & $\begin{array}{l}\text { Pilih menu master mahasiswa kemudian } \\
\text { tekan tombol tambah, ubah dan hapus } \\
\text { serta sistem akan menampilkan } \\
\text { perubahan data mahasiswa }\end{array}$ & $\begin{array}{l}\text { Menampilkan data dan } \\
\text { menyimpannya ke dalam } \\
\text { database. }\end{array}$ & Berhasil \\
\hline 4 & $\begin{array}{l}\text { Transakasi } \\
\text { Pengajuan } \\
\text { Beasiswa }\end{array}$ & $\begin{array}{l}\text { Pilih menu Resgistrasi kemudian input } \\
\text { data dan tekan registrasi. Selanjutnya } \\
\text { input data pengajuan dan tekan tombol } \\
\text { daftar }\end{array}$ & $\begin{array}{l}\text { Menampilkan data } \\
\text { pengajuan dan } \\
\text { menyimpannya ke dalam } \\
\text { database. }\end{array}$ & Berhasil \\
\hline 5 & $\begin{array}{l}\text { Transaksi } \\
\text { Data } \\
\text { Training }\end{array}$ & $\begin{array}{l}\text { Pilih menu transaksi data training } \\
\text { kemudian pilih dtombol detail pada } \\
\text { menu aksi untuk menampilkan data } \\
\text { detail training }\end{array}$ & $\begin{array}{l}\text { Menampilkan data } \\
\text { training yang telah } \\
\text { tersimpan pada database }\end{array}$ & Berhasil \\
\hline 6 & $\begin{array}{l}\text { Transaksi } \\
\text { Penentuan } \\
\text { Beasiswa }\end{array}$ & $\begin{array}{l}\text { Pilih menu transaksi penentuan beasiswa } \\
\text { kemudian tekan tombol proses maka } \\
\text { sistem akan menentukan beasiswa } \\
\text { dengan metode K-NN dan sistem akan } \\
\text { menampilkan hasil penentuan beasiswa. }\end{array}$ & $\begin{array}{l}\text { Menampilkan data } \\
\text { pengajuan, data hasil } \\
\text { perhitungan }\end{array}$ & Berhasil \\
\hline 7 & $\begin{array}{l}\text { Transaksi } \\
\text { ACC } \\
\text { Verifikasi }\end{array}$ & $\begin{array}{l}\text { Pilih menu transaksi verifikasi tekan } \\
\text { tombol detail untuk menampilkan data } \\
\text { detail pengajuan dan tekan tombol ACC. }\end{array}$ & $\begin{array}{l}\text { Menampilkan data } \\
\text { kandidat dan menyimpan } \\
\text { perubahan status ke } \\
\text { database }\end{array}$ & Berhasil \\
\hline 8 & $\begin{array}{l}\text { Cetak } \\
\text { Laporan }\end{array}$ & $\begin{array}{l}\text { Pilih menu laporan kemudian tekan } \\
\text { tombol detail dan tekan tombol PDF }\end{array}$ & $\begin{array}{l}\text { Menampilkan data laporan } \\
\text { beasiswa dengan format } \\
\text { PDF }\end{array}$ & Berhasil \\
\hline
\end{tabular}

5. Deployment

Tahap deployment merupakan tahapan terakhir dalam tahapan pembuatan sistem. Pada 
tahap ini dilakukan implementasi software yang akan digunakan oleh pengguna, pemeliharaan software secara berkala, evaluasi software dan pengembangan software berdasarkan umpan balik yang diberikan. Proses tersebut bertujuan agar sistem dapat tetap berjalan dan berkembang sesuai dengan fungsinya.

\section{B. Perhitungan Metode KNN}

Langkah-langkah perhitungan pada sistem pendukung keputusan penentuan jenis beasiswa menggunakan metode KNN ini adalah sebagai berikut:

Tabel 2. Kriteria Beasiswa

\begin{tabular}{cccccc}
\hline \multirow{2}{*}{ No } & \multirow{2}{*}{ Jenis Beasiswa } & Min Semester & IPK & Penghasilan & Tanggungan \\
\cline { 3 - 6 } & & 3 & 3.25 & $>=1$ juta & $>=1$ \\
\hline 1 & PPA & 2 & 3.00 & $<=1$ juta & $>=2$ \\
\hline 2 & PPLP-PT-PGRI & 3 & 3.25 & $>=1$ juta & $>=2$ \\
\hline 3 & BNI & 5 & 3.25 & $>=1$ juta & $>=1$ \\
\hline 4 & CIMB Niaga & &
\end{tabular}

Adapun data training yang digunakan merupakan data pengajuan beasiswa PPA pada tahun ajaran 2016/2017, PPLP PT PGRI 2015/2016, BNI 2016/2017 dan CIMB Niaga 2016/2017. Berikut contoh perhitungan pada beasiswa PPA dapat dilihat pada tabel 3.

Tabel 3. Data Training PPA 2016/2017

\begin{tabular}{ccccccc}
\hline No & NPM & Semester & IPK & Penghasilan & Tanggungan & Beasiswa \\
\hline 1 & 140401140347 & 7 & 3,72 & 750000 & 4 & PPA \\
\hline 2 & 150401080147 & 5 & 3,55 & 1158659 & 2 & PPA \\
\hline 3 & 140401090083 & 7 & 3,75 & 2000000 & 3 & PPA \\
\hline 4 & 140404010097 & 7 & 3,61 & 1200000 & 3 & PPA \\
\hline 5 & 140401060163 & 7 & 3,71 & 1000000 & 5 & PPA \\
\hline 6 & 140403010040 & 7 & 3,55 & 4343500 & 3 & PPA \\
\hline 7 & 140401140215 & 7 & 3,8 & 1500000 & 2 & PPA \\
\hline 8 & 150406030024 & 5 & 3,25 & 700000 & 6 & PPA \\
\hline 9 & 140404010231 & 7 & 3,28 & 1350000 & 2 & PPA \\
\hline 10 & 140401150040 & 7 & 3,5 & 500000 & 2 & PPA \\
\hline 11 & 150404010140 & 5 & 3,6 & 1000000 & 4 & PPA \\
\hline 12 & 150401150040 & 5 & 3,46 & 740000 & 3 & PPA \\
\hline 13 & 150401010045 & 5 & 3,6 & 2000000 & 4 & PPA \\
\hline 14 & 140401150043 & 7 & 3,54 & 1000000 & 2 & PPA \\
\hline 15 & 150401090009 & 5 & 3,58 & 300000 & 4 & PPA \\
\hline 16 & 140401080004 & 7 & 3,58 & 2000000 & 3 & PPA \\
\hline 17 & 150401140063 & 5 & 3,66 & 2207000 & 2 & PPA \\
\hline 18 & 150401080062 & 5 & 3,45 & 800000 & 2 & PPA \\
\hline$\ldots$ & & & & & & \\
\hline 35 & 150401020050 & 5 & 3,55 & 450000 & 4 & PPA \\
\hline
\end{tabular}

Dalam penelitian ini ada 35 data sebagai data taining dan 35 data sebagai data sampel serta menggunakan $\mathrm{K}=3$ untuk menentukan banyaknya tetangga terdekat.Tabel 4 merupakan pemaparan data sampel pengajuan beasiswa:

Tabel 4. Data Sampel PPA 


\begin{tabular}{ccccccc}
\hline No & NPM & Semester & IPK & Penghasilan & Tanggungan & Keterangan \\
\hline 1 & 150401010079 & 5 & 3,55 & 450000 & 4 & $?$ \\
\hline 2 & 150401070003 & 5 & 3,64 & 2000000 & 3 & $?$ \\
\hline 3 & 150404010038 & 5 & 3,73 & 750000 & 3 & $?$ \\
\hline 4 & 150401080026 & 5 & 3,56 & 2715300 & 7 & $?$ \\
\hline 5 & 140403010058 & 5 & 3,45 & 900000 & 4 & $?$ \\
\hline 6 & 140401070080 & 7 & 3,45 & 970000 & 3 & $?$ \\
\hline 7 & 150401040084 & 7 & 3,61 & 1300000 & 3 & $?$ \\
\hline 8 & 150406030060 & 5 & 3,34 & 1000000 & 7 & $?$ \\
\hline 9 & 150401010031 & 5 & 3,53 & 500000 & 5 & $?$ \\
\hline 10 & 140401090054 & 5 & 3,84 & 1200000 & 2 & $?$ \\
\hline 11 & 150406030078 & 7 & 3,84 & 3000000 & 2 & $?$ \\
\hline 12 & 140403010025 & 5 & 3,52 & 500000 & 2 & $?$ \\
\hline 13 & 150401060127 & 7 & 3,65 & 1500000 & 3 & $?$ \\
\hline 14 & 150401020023 & 5 & 3,36 & 1000000 & 4 & $?$ \\
\hline 150404010180 & 5 & 3,55 & 1250000 & 3 & $?$ \\
\hline 140401040058 & 5 & 3,83 & 2100000 & 3 & $?$ \\
\hline 150404020014 & 7 & 3,62 & 3657000 & 4 & $?$ \\
\hline 180401010074 & 5 & 3,59 & 1582200 & 3 & $?$ \\
\hline
\end{tabular}

Untuk memperkecil jumlah jarak data maka dapat menggunakan rumus min max normalisasi, berikut adalah hasil normalisasi data sampel PPA:

Tabel 5. Normalisasi Data Sampel PPA

\begin{tabular}{ccccccc}
\hline No & NPM & Semester & IPK & Penghasilan & Tanggungan & Keterangan \\
\hline 1 & 150401010079 & 0,00 & 0,73 & 0,33 & 0,25 & $?$ \\
\hline 2 & 150401070003 & 0,00 & 0,73 & 0,09 & 0,25 & $?$ \\
\hline 3 & 150404010038 & 0,00 & 0,52 & 0,47 & 0,75 & $?$ \\
\hline 4 & 150401080026 & 0,00 & 0,66 & 0,12 & 0,38 & $?$ \\
\hline 5 & 140403010058 & 1,00 & 0,81 & 0,13 & 0,25 & $?$ \\
\hline 6 & 140401070080 & 1,00 & 0,53 & 0,20 & 0,25 & $?$ \\
\hline 7 & 150401040084 & 0,00 & 0,35 & 0,14 & 0,75 & $?$ \\
\hline 9 & 150406030060 & 0,00 & 0,35 & 0,04 & 0,50 & $?$ \\
\hline 10 & 150401010031 & 0,00 & 0,61 & 0,18 & 0,13 & $?$ \\
\hline 11 & 140401090054 & 1,00 & 0,18 & 0,53 & 0,13 & $?$ \\
\hline 12 & 140406030078 & 0,00 & 0,48 & 0,04 & 0,13 & $?$ \\
\hline 13 & 150401060127 & 0,00 & 0,98 & 0,14 & 0,38 & $?$ \\
\hline 14 & 150401020023 & 0,00 & 0,47 & 0,19 & 0,25 & $?$ \\
\hline 15 & 150404010180 & 0,00 & 0,68 & 0,35 & 0,25 & $?$ \\
\hline 16 & 140401040058 & 1,00 & 0,21 & 0,66 & 0,38 & $?$ \\
\hline 18 & 150404020014 & 0,00 & 0,52 & 0,25 & 0,25 & $?$ \\
\hline$\ldots$ & 140401010074 & 1,00 & 0,97 & 0,77 & 0,38 & $?$ \\
\hline 35 & 140401090071 & 1,00 & 0,56 & 0,09 & 0,25 & \\
\hline & & & & & 0,24 & $?$ \\
\hline
\end{tabular}

Kemudian membandingkan setiap data sampel dengan data training untuk menghitung jarak terdekat dengan menggunakan rumus Euclidean Distance sebagai berikut: 


$$
\begin{gathered}
d \mathbf{~ 1}=\sqrt{\sum_{i}^{n}(1,00-0,00)^{2}+(0.80-0,73)^{2}+(0,11-0,33)^{2}+(0,40-0,25)^{2}} \\
\quad=12=\sqrt{\sum_{i}^{n}(0,00-0,00)^{2}+(0,51-0,73)^{2}+(0,21-0,33)^{2}+(0,00-0,25)^{2}} \\
=0,35
\end{gathered}
$$

Pada perhitungan rumus diatas menjelaskan pencarian jarak terdekat dengan rumus Euclidean Distance. Dimana rumus $d l$ merupakan perbandingan antara data training 1 dengan data sampel 1 sedangkan $d 2$ perbandingan data training 2 dengan data sampel 1 begitu pula seterusnya.

Tabel 6 merupakan tabel hasil perhitungan jarak terdekat antara data sampel 1 dengan data training. Hasil dari perhitungan tersebut adalah sebagai berikut:

Tabel 6. Hasil Perhitungan Jarak Terdekat

\begin{tabular}{ccccccc}
\hline No & NPM & Semester & IPK & Penghasilan & Tanggungan & Jarak \\
\hline 1 & 140401140347 & 1,00 & 0,80 & 0,11 & 0,40 & 1,04 \\
\hline 2 & 150401080147 & 0,00 & 0,51 & 0,21 & 0,00 & 0,35 \\
\hline 3 & 140401090083 & 1,00 & 0,85 & 0,42 & 0,20 & 1,01 \\
\hline 4 & 140404010097 & 1,00 & 0,61 & 0,22 & 0,20 & 1,01 \\
\hline 5 & 140401060163 & 1,00 & 0,78 & 0,17 & 0,60 & 1,07 \\
\hline 6 & 140403010040 & 1,00 & 0,51 & 1,00 & 0,20 & 1,22 \\
\hline 7 & 140401140215 & 1,00 & 0,93 & 0,30 & 0,00 & 1,05 \\
\hline 8 & 150406030024 & 0,00 & 0,00 & 0,10 & 0,80 & 0,94 \\
\hline 9 & 140404010231 & 1,00 & 0,05 & 0,26 & 0,00 & 1,23 \\
\hline 10 & 140401150040 & 1,00 & 0,42 & 0,05 & 0,00 & 1,11 \\
\hline 11 & 150404010140 & 0,00 & 0,59 & 0,17 & 0,40 & 0,26 \\
\hline 12 & 150401150040 & 0,00 & 0,36 & 0,11 & 0,20 & 0,44 \\
\hline 13 & 150401010045 & 0,00 & 0,59 & 0,42 & 0,40 & 0,22 \\
\hline 14 & 140401150043 & 1,00 & 0,49 & 0,17 & 0,00 & 1,07 \\
\hline 15 & 150401090009 & 0,00 & 0,56 & 0,00 & 0,40 & 0,40 \\
\hline 16 & 140401080004 & 1,00 & 0,56 & 0,42 & 0,20 & 1,02 \\
\hline 17 & 150401140063 & 0,00 & 0,69 & 0,47 & 0,00 & 0,29 \\
\hline 18 & 150401080062 & 1,00 & 0,80 & 0,11 & 0,40 & 1,04 \\
\hline$\ldots$ & & & & & & \\
\hline 35 & 150401020050 & 0,00 & 0,51 & 0,04 & 0,40 & 0,40 \\
\hline
\end{tabular}

Hasil pengklasifikasian jenis beasiswa diperoleh setelah melakukan pengurutan jarak dimana jarak terkecil merupakan jarak paling dekat. Data kategori mayoritas yang muncul akan dijadikan sebagai kategori terpilih, hasil pengklasifikasian tersebut seperti pada tabel 7:

Tabel 7. Perhitungan K=3

\begin{tabular}{cccc}
\hline No & NPM & Jarak & Keterangan \\
\hline 1 & 150401140211 & 0,17 & TIDAK DAPAT \\
\hline 2 & 150401040001 & 0,18 & DAPAT \\
\hline 3 & 150401010045 & 0,22 & DAPAT \\
\hline
\end{tabular}

Pada tabel 11 dapat disimpulkan bahwa hasil akhir yang diperoleh mahasiswa dengan npm 150401010079 pada data sampel PPA tersebut adalah mendapatkan beasiswa. Hal ini dibuktikan oleh kategori yang paling banyak muncul adalah "DAPAT". 


\section{PENUTUP}

Sistem pendukung keputusan ini dapat mempermudah staf dan mahasiswa dalam melakukan penentuan dan pengajuan beasiswa. Dan Telah dilakukan pengujian aplikasi penentuan jenis beasiswa oleh mahasiswa, staf dan Kepala BAK dan mengisi kuesioner, terdapat $86 \%$ responden dengan hasil rentang jawaban tertinggi yaitu $100 \%$ yang menyatakan setuju jika aplikasi presensi digunakan pada saat absensi perkuliahan. Sistem pendukung keputusan penentuan beasiswa dapat mengklasifikasikan data untuk membantu mempercepat pekerjaan staf BAK dalam menentukan jenis beasiswa. Hasil uji penentuan beasiswa menunjukan bahwa sistem pendukung keputusan yang dibuat dengan menggunakan algoritma K-NN menghasilkan keluaran yang sama dengan perhitungan manual yang dilakukan dengan microsoft excel, dimana keluaran sistem berupa nilai terendah yang dijadikan kasus terdekat untuk mengklasifikasi kasus baru sama dengan hasil perhitungan microsoft excel.

Berdasarkan hasil kesimpulan diatas, diharapkan pada pengembangan Sistem Pendukung Keputusan Penentuan Jenis Beasiswa menggunakan metode K-NN selanjutnya dapat dilakukan penelitian lebih lanjut dalam penentuan nilai $\mathrm{K}$ agar memperoleh nilai $\mathrm{K}$ terbaik yang akan digunakan dalam proses pengklasifikasian. Selain itu, perlu adanya pengembangan untuk kriteria-keteria yang sifatnya sulit terukur seperti kriteria semester.

\section{DAFTAR PUSTAKA}

Helilintar, R., Winaryo, W. W., \& Fatta, H. A. (2016). Penerapan Metode SAW dan Fuzzy Dalam Sistem Pendukung Keputusan Penerima Beasiswa. ISSN: 2354-5771, 2 (2): 89101.

Mustaqbal, M., Firdaus, R. F., \& Rahmadi, H. (2015). Pengujian Aplikasi Menggunakan Black Box Testing Boundary Value Analysis (Studi Kasus: Aplikasi Prediksi Kelulusan SNMPTN). ISSN:2407-3911.

Pressman, R. S. (2015). Software Engineering A Practitioner's Approach. New York: McCrawHill Education.

Yulianti, E., \& Nurdia, Y. A. (2018). Sistem Pendukung Keputusan Penerima Bantuan Siswa Miskin (BSM) Berbasis Online dengan Metode KNN (K-Nearest Neighbor)(Studi Kasus: SMPN 1 Koto XI Tarusan). ISSN:2338-2734, 12-17. 